\title{
How is the State Perceived as Fair? A Literature Review of Social Identity-Based Procedural Justice in the National Context
}

\author{
Andina Mega Larasati ${ }^{* 1}$, Joevarian Hudiyana ${ }^{2}$, Hamdi Muluk ${ }^{3}$ \\ ${ }_{1,2,3}$ Faculty of Psychology, Universitas Indonesia
}

\author{
Submitted 15 February 2021 Accepted 16 May 2021 Published 2 December 2021
}

\begin{abstract}
Justice is relevant in various domains of life, including the state. The social identity-based procedural justice theories (Group Value Model and Group Engagement Model) emphasize the importance of procedural justice from the authority in signaling the group's inclusion and respect, thus increasing individuals' cooperation and compliance. This article aims to critically review published literature using the two models in a national context, of which there were inconsistent findings regarding the role of group identification. Three issues are underlying this inconsistency. First, both models could be applied when national identity was salient, such as legal compliance (to taxation and traffic law). Second, perceived police legitimacy is a better mediator when the national identity was not salient (e. g. cooperation in counter-terrorism and crowd policing). Third, the effect of procedural justice depends on the motivation to secure identity (which is generally higher among minority/marginalized groups). As both models are strongly bound by context, the author suggests controlling police-national identity prototypicality on studies about police procedural justice, attitude toward outgroup and relational identification with the police on studies involving intergroup conflict, and uncertainty about membership status on studies toward minority groups. Hopefully, this article could contribute references and encourage related studies in Indonesia.
\end{abstract}

Keywords: group value; group engagement; procedural justice; social identity; state

\section{Introduction}

During the Coronavirus Disease (Covid-19) outbreak that has been going on since the beginning of 2020, various socio-political issues have stirred up Indonesian citizens. Some of these issues sparked protests (which drew pros and cons for causing crowds) because of the perceived procedural injustice (decision-making processes). Some examples include the \#TolakOmnibusLaw protest due to its suspicious ratification and the protest from the Islamic Defenders Front (FPI) which demanded an investigation into the death of their members on the hands of the police (Rosana, 2020). Studies about justice in the national social/political realm will certainly be intriguing and beneficial. T. R. Tyler and Blader (2003) have proposed a model of procedural justice based on social identity which is claimed to be relevant in various group contexts. However, the model was more supported in the organizational context and less consistent in the national context (such as the relations of citizens with government

*Address for correspondence: andina.mega@ui.ac.id 


\section{Larasati et al || Literature Review of Social Identity}

authorities). This article reviews the studies on procedural justice in the national context with the aim of extracting some notable issues.

Justice theories were built on the basic premise that "judgments about justice shape human thoughts, feelings, and behavior" (T. R. Tyler \& Blader, 2003). Among the various theories that have developed, some are no longer used as references due to lack of empirical evidence. Most of the literature discusses two types of justice, namely distributive and procedural. Initially, researchers focused on distributive justice, namely the fair distribution of results/resources. Humans feel dissatisfied when they get results that are either less or more than the distribution that is considered fair. However, after some time, the focus shifted to procedural justice, namely social situations where the norms of entitlement and decency are met (Lind \& Tyler, 1988). Distributive justice judgment is prone to bias, ineffective in resolving conflicts, and its effect is not as large as procedural justice judgment (T. R. Tyler \& Blader, 2003). Therefore, this article will focus on the latest theories of procedural justice. We will briefly describe the development of these theories.

The definition of procedural justice itself has evolved over time. According to the control theory by Thibaut et al. (1974), a procedure is said to be fair if it gives all parties a voice in decision-making. This assumption departs from the Social Exchange Model which emphasizes the importance of rewards obtained from interactions and groups. The justice assessment model by Leventhal (1980) extends the criteria for procedural justice assessment: The procedure (1) is applied consistently to each person and time (consistency); (2) is not influenced by personal interests (bias-suppression); (3) is based on accurate and informed information (accuracy); (4) allows revision or cancellation of decisions (correctability); (5) contains views of all individuals/subgroups (representativeness alias process control); and (6) is in line with individual moral and ethical values (ethicality). Which rules are used to assess procedural justice may vary from time to time.

Lind and Tyler (1988) criticized the aforementioned theories for being too instrumental and individual-oriented, i.e. implying that individuals control decision-making for personal gain. They found that individuals valued the opportunity to speak even if it did not affect outcomes. This finding initiates a shift in focus from the aspect of decision making (instrumental) to the aspect of interpersonal treatment (non-instrumental). They also coined the Group Value Model (GVM) based on Social Identity Theory (SIT). Its basic assumption is that individuals are motivated to have positive self-esteem, one way by evaluating their status in groups that are relevant to themselves. Because authorities provide important information about their status, individuals tend to pay attention to non-instrumental factors (interpersonal treatment) such as neutrality, trust, and standing in assessing procedural justice. The fair treatment of authority indicates that the group recognizes and respects the individual, thus affecting attitudes toward authority especially when the group is important to the individual (T. R. Tyler, 1989; T. R. Tyler \& Lind, 1992). However, the instrumental factor (control in decision making) is more decisive in the assessment of procedural justice when there is a dispute or the outcome is not favorable (T. R. Tyler, 1989).

T. R. Tyler and Blader (2003) developed the Group Engagement Model (GEM) to explain how procedural justice affects cooperative behavior in groups, emphasizing the importance of social 
identity over individual interests. In every group, from family, organization/industry, to the state, the dynamics of relationship between individuals and groups greatly determine attitudes/behaviors towards groups. According to SIT, individuals have a need for a positive identity and hence are willing to work with groups that give them a positive social identity. GEM proposes the 'social identity mediation hypothesis': Procedural justice judgment is the key determinant of group identity judgment, which then determines the willingness of members to cooperate with the group. Procedural justice judgment consists of 2 main elements: decision making (participation opportunities and neutral forum) and interpersonal quality of treatment (trusted authorities and treats members with dignity and respect). Identity judgment consists of three constructs, namely group identification (how much the individual defines himself as a member of the group), pride in the group, and respect that reflects status in the group. Resource judgment (including distributive justice and how favorable the outcome) also determined cooperative behavior, but voluntary (discretionary) rather than mandatory (mandatory) cooperative behavior was mediated by identity judgment. The process-based regulation or PBRM model (T. R. Tyler \& Huo, 2002) also argues that procedural justice makes citizens feel accepted and valued by the state, thus regulating themselves by legitimizing, cooperating and obeying authorities.

In social psychology, the latest procedural justice theory (GEM and GVM) were based on SIT. Considering that SIT itself has undergone various developments (e.g. the emergence of various new models), a review of the application of these models is considered very important. In addition, these models have practical implications and are very broad in scope: from small groups, industries/organizations, to countries. GEM and GVM have been widely supported within the scope of the organization/industry (Radburn \& Stott, 2018). However, the national context (the relationship between citizens and state authorities) has a wide and varied scope which can complicate the justice judgment. Studies in the national context can cover different types of behavior (e.g. obeying traffic laws, paying taxes, helping to prevent crime) and state authorities (government, tax authorities, police, courts). The dynamics of intergroup relations are also inevitable in certain situations/regions. This presents its own challenges for generalizing theories of justice. This article reviews studies based on GEM and GVM (involving procedural justice variables and group identification) in the national context to clarify as to when hypotheses are supported and not supported, the potential issues behind them, and the alternative mechanisms. For this reason, the author also reviews PBRM which discusses the relationship between procedural justice and the legitimacy of authority.

Testing $\mathcal{E}$ Application of Theory

According to SIT, group membership has an important function in shaping self-definition, well-being and self-esteem (Hogg \& Abrams, 1988). Groups help us define who we are and evaluate our status. This process consists of two stages, namely social categorization (using group membership to define oneself) and linking self-esteem to group membership. According to GEM and GVM, the motivation to have a positive identity in the group (identity security) goes beyond the instrumental motive for securing outcome (outcome security). While SIT focuses more on intergroup dynamics, GVM and GEM focus on intragroup dynamics (T. Tyler et al., 1996). SIT argues that an individual's self-esteem is 
influenced by the general evaluation of his group (compared to other groups). However, according to GEM and GVM, an individual's self-esteem is influenced by the evaluation of positive treatment from the authority, which indicates that one is accepted and valued by the group. Before reviewing recent studies, below are the initial studies that provide empirical support for GVM, GEM, and PBRM.

T. R. Tyler (1989) examines GVM and control theory in the context of American experiences with police and courts. Through a telephone survey, he aimed to find out when did participants care more about control over the decision-making process than non-instrumental/relational factors (neutrality, trust, standing) that were not related to the outcome. The independent variables in this study were outcome favorability (absolute and relative quality of the results received), process control (voice and decision), and non-instrumental factors. The dependent variable was the assessment of procedural and distributive justice, affect on authority, and the overall assessment of justice. GVM was supported: Procedural justice judgment was determined more by non-instrumental factors, especially trust and standing which emphasizes relationships with groups, rather than neutrality and outcome favorability which are still related to results. Participants with high commitment to the group tend to pay more attention to non-instrumental factors, and ethnic minority participants emphasize the standing factor more than white participants. This shows that procedural justice implies inclusion, especially for individuals who care about their relationship with the group.

The GVM assumption that procedural justice provides identity-relevant information was corroborated by the findings that relational factors judgment predicts self-esteem, mediated by pride and respect in the context of family, university, and country (T. Tyler et al., 1996). In addition, they found the effect of these relational factors on compliance, extrarole behavior, and commitment in four groups (family, company, university, and country). In general, the model was proven in all contexts, but the relationship among variables was strongest in the family context and weakest in the country context. This is presumably because parents are relatively easy to identify as authorities and interactions with them are more frequent.

GEM was first demonstrated in a survey of 404 employees (T. R. Tyler \& Blader, 2000). First, identity judgment (identification, pride, and respect) shapes cooperative attitudes, values, and behavior. The role of identity judgment is greater in shaping discretionary (voluntary) cooperative behavior than mandatory. Second, resource judgment (obtained from the group) affects discretionary cooperative attitudes, values, and behavior indirectly through identity judgment. Third, procedural justice is the main determinant of identity judgment, so that its influence on cooperation is also mediated by identity. GEM was again supported in two studies (Blader \& Tyler, 2009) on employee extrarole behavior (voluntary positive behavior outside of job descriptions) as assessed by supervisors. Social identity is more predictive of cooperation when it consists of all three aspects rather than just identification. This indicates the importance of the evaluative aspect (the value assigned to the group) because it determines how important identity influences thoughts/feelings about oneself.

Sunshine and Tyler (2003) examined PBRM in the context of policing before and after the events of September 11, on white, African-American and Hispanic residents of New York. The following are the assumptions of PBRM: (1) Perception of police legitimacy is more or as important as perceived 


\section{Larasati et al || Literature Review of Social Identity}

legal risk (instrumental judgment) in predicting law compliance, cooperative behavior with police, and police empowerment; (2) Legitimacy judgment is more influenced by procedural justice judgment than instrumental judgment (distributive justice, police performance effectiveness, perceived risk of punishment). Legitimacy is the perception of the obligation to obey the legal authority, trust in police institutions and individuals, and positive feelings towards the police. The study results supported all of the assumptions. Instrumental judgment also influenced the post-terrorism police empowerment, presumably because residents felt more threatened. There was no significant difference among ethnic groups, implying that PBRM applies universally.

GEM, GVM, and PBRM have been used as references for further studies (over the last 15 years) in the national context, although the results were not entirely consistent. We would like to discuss these studies as categorized by their sub-context.

\section{Discussion}

\section{Compliance with the Government in General}

T. R. Tyler (2009) applied GEM to national context through a survey of South African communities that have a history of social conflict and are in transition from an autocratic state to a unitary and democratic state (circa 2000). The perception of government's procedural justice (in general) predicts compliance with the law in the form of less lawlessness (claiming undeserved government assistance, not paying for electricity and water, damaging public property) mediated by national identification. Thus, social identity mediation hypothesis was supported in the context of state, particularly the government in general (instead of specific institutions). Thus far we found 4 similar studies in Indonesia. Kuncoro (2001) found that control and especially interactional justice predict the assessment of government procedural justice by earthquake victims in Yogyakarta. Muluk and Budiarti (2008) found that social dominance orientation predicts negatively, while trust in the government positively predicts procedural and distributive justice judgment of the increased quota for women legislators. Faturochman and Ancok (2001) found that the treatment of state-owned plantation company (PT. Perkebunan Nusantara/PTPN) towards farmers (coercive vs. non-coercive) influenced students' assessment of procedural and distributive justice. From the perspective of the farmers themselves, the government was considered unfair because PTPN (supported by the local government) required farmers to surrender their land without actually being consulted (Faturochman, 2002; Faturochman \& Walgito, 2002). These studies confirmed the role of relational factors in assessing procedural justice (in line with GVM), although they did not examine the impact of procedural justice and national identification.

\section{Compliance with Laws (Tax and Traffic Rule}

Tax compliance is a form of cooperation between state authorities and the public. Taxes are an important state resource to carry out the widest possible development. Procedural justice positively predicts tax compliance motivation and negatively predicts tax violation motivation, mediated by 


\section{Larasati et al || Literature Review of Social Identity}

national identification (Hartner et al., 2008; Hartner-Tiefenthaler et al., 2013). Its mediating effect also applies to tax violators and its coefficient exceeds that of the tax authorities legitimacy (Murphy et al., 2015). There is also a moderating effect of national identification: Procedural justice negatively predicts non-compliance with paying taxes when the national identification score is high (Wenzel, 2002). This finding is consistent with GVM, that fair treatment of authority implies inclusion for members who consider the group important (T. R. Tyler, 1989). However, the moderating effect only occured in easily traceable violations such as reporting additional income below the true nominal. Subtle violations such as reducing the nominal cash income reported and tax minimization are more predictable by instrumental factors: deterrence (perceived probability of being sanctioned) and outcome favorability (acceptance of the tax authority's decision).

In Indonesia, procedural justice also predicts tax compliance, mediated by trust in tax authorities (Ratmono, 2014; Zelmiyanti, 2016) and the government (Putong, 2017). These studies adhere to fairness heuristic theory: Justice judgment is used as a heuristic to assess whether authority can be trusted, which in turn impacts the decisions to contribute to the group (Lind, 2001). This assumption is more or less in line with PBRM because trust is one aspect of legitimacy (Sunshine \& Tyler, 2003). The mediating effect of national identification has never been studied in Indonesia, although there is evidence of the influence of nationalism (i.e. pride to be an Indonesian citizen) on taxpayer compliance (Hanifah \& Yudianto, 2019; Purnamasari et al., 2018). Compliance with the law also concerns traffic rules, with the traffic police as the authority. Police procedural justice when intercepting drivers predicts perceived legitimacy and the intention of future traffic violations, mediated by national identification (Bradford et al., 2015). Thus, GEM was supported in this context. There was no association between legitimacy and traffic violations. The researchers argued that traffic rules are more associated with potentially hurting fellow citizens than obeying the law.

\section{Compliance/Cooperation with the Police}

\section{In General}

In the relationship between police and society in general, procedural justice predicts perceived legitimacy (Bradford et al., 2016; Bradford et al., 2014; Pehrson et al., 2017), compliance and cooperation with the police (Bradford et al., 2014; Pehrson et al., 2017). Supporting GEM, national identification partially mediates the relationship between procedural justice and legitimacy (Bradford et al., 2016; Bradford et al., 2014) \& cooperative behavior aka reporting crimes to the police (Bradford et al., 2014). Some findings also support GVM. First, procedural justice increased national identification, especially in participants with low national identification (Bradford et al., 2014). Second, procedural justice predicted cooperative behavior with the police, partially mediated by a sense of belongingness (affective aspect) in UK especially in non-UK citizens (Bradford et al., 2014). In UK citizens, only perceived legitimacy (evaluative aspect) mediated the relationship between procedural justice and cooperative behavior. This implies that the need for inclusion was greater for non-UK residents whose identities were more uncertain. Third, procedural justice increased the legitimacy of authority 
behavior (T. R. Tyler \& Blader, 2003) especially in citizens who initially had low ethnic identification, but increased ethnic identification was followed by increased legitimacy (Bradford et al., 2014).

According to researchers, loose ties to groups can encourage perception of anomie (disruption of social order and authority) which increases sensitivity to the treatment of authority. The study of Pehrson et al. (2017) gave an exception: Identification did not mediate the effect of the quality of police treatment (a relational factor in procedural justice) on legitimacy, cooperation \& compliance. Significant mediators were perceived justice (procedural and distributive) and goal alignment (the suitability of the goals of police and the public). It is noteworthy that group identification was defined as 'solidarity, satisfaction, and centrality with society' instead of explicit national identification. The term 'society' could be perceived differently and does not make the national context salient. Moreover, the country where the study took place (Northern Ireland) has a history of conflict between the Catholic and Protestant communities, adding to the potential ambiguity of the term.

Thus far we found two studies on police procedural justice in Indonesia. According to PBRM, perceived procedural and distributive justice were found to predict trust in the police (Nurpratiwi, 2017). Davies et al. (2014) conducted an ethnographic study (through interviews, participatory observation, and multimedia analysis) on citizen perceptions of the Indonesian police. Their findings support the GVM: Procedural justice, especially the friendly and respectful treatment of the police, determined the assessment and support of the police more than instrumental factors (the ability of the police to deal with crime). This is thought to be influenced by (1) the culture of avoiding shame (inherent in individuals and groups) as a result of police treatment, and (2) the expectation for the police to maintain social cohesion in a pluralistic country with a history of conflict and dictatorship.

\section{In Minority \& Marginalized Groups}

Social identity mechanisms are very relevant to the issue of minority and marginalized groups. Their distrust and reluctance to cooperate with the police is influenced by the unpleasant personal/collective experiences of the police (T. R. Tyler, 2001). In addition to threatening self-esteem, such treatment can affect identification with the police, the wider community, and the state by communicating that the state does not value them. Studies involving these groups are necessary for at least several reasons: (1) to examine the generalizability of mediating national identification between minority/marginalized groups and the general population; (2) a history of relatively frequent conflicts with the police; (3) cooperation from minority groups is crucial for terrorism prevention.

Studies for the first reason tested GEM in a pair of populations: first-generation and second-generation of immigrants from the UK to Australia (Sargeant et al., 2020); the general public and the homeless in the UK (Kyprianides et al., 2021). Sargeant et al. (2020) found that procedural justice (and not effectiveness) of police predicted cooperation, mediated partially by identification with Australia and especially relational identification (feelings of solidarity \& similarity) with police. This suggests that the police could be seen as a separate social category, and that national identity is less relevant to some. The effect of procedural justice on identification with the police was stronger in second-generation immigrants, suggesting the importance of the relational factor as it provides 
information about their status and worth in society. Kyprianides et al. (2021) found in both the general population and the homeless, procedural justice predicts legitimacy and cooperation, mediated by relational identification and national identification. Legitimacy also mediated the relationship between procedural justice and cooperation, but only in the general population. The relative importance of the identity mechanism for the homeless is reasonable because they often have informal contact with the police, so that the police are also seen as individuals. Sargeant et al. (2014) examined the moderating effect of national identification on the effect of procedural justice on legitimacy, through an experimental police alcohol use test on Australian drivers. Procedural justice was manipulated through dialogue with the police (neutral vs. fair). According to GVM, procedural justice is thought to increase the police legitimacy in citizens with high national identification. Perceived procedural justice did predict legitimacy, but was not moderated by national identification. According to researchers, Australia receives a large number of immigrants every year so that the ability of the authorities to maintain justice and order is taken into account by all parties.

Murphy (2013) and Sargeant et al. (2020) examined ethnic Indians, Arabs and Vietnamese in Australia who represent the largest ethnicity of immigrants there and have a history of conflict with the police. Perceived procedural justice predicted cooperation through trust in the police. There was a moderating effect of ethnic identification: Procedural justice predicted trust in the police only in citizens with high ethnic identification. This is contrary to the initial assumption that refers to GVM, that the effect of procedural justice is more meaningful for citizens with low ethnic identification (assuming that it implies high national identification). This finding indicates that ethnic identification does not necessarily reduce the need for social inclusion from the state. Participants with high ethnic identification may actually feel the most marginalized. The uncertainty that ethnic minorities feel about their status in the state increases their sensitivity to procedural justice that informs acceptance, appreciation, and recognition from the state. National identification was positively related to procedural justice and ethnic identification, predicting trust and cooperation, but had no mediating and moderating effect.

Sargeant et al. (2020) found different mechanisms in individuals with different motivational postures. Referring to social distance theory (Braithwaite, 2009), motivational posture or willingness to interact positively and acknowledge authority status is divided into five categories: commitment (belief in the police legitimacy, that obeying the police is the right thing); capitulation (obedience simply to avoid any troubles with the police); resistance (acceptance of the police as a legitimate institution of social control, but also rejection of the way they use power); disengagement (rejection of the police \& the applicable legal system); and game-playing (rejection and rebellion when the goals of authority are not in accordance with personal interests). While commitment and capitulation are positive attitudes (compliance), the rest are negative attitudes (defiance) towards authority. The researchers aimed to know the social identity process in the relationship between procedural justice and the five postures. In addition to GEM and GVM, they also tested the Uncertainty Management Model (UMM), which posits that uncertainty about status in the group (indicated by low national identification) triggers unpleasant affective and cognitive state. Procedural justice is becoming more 


\section{Larasati et al || Literature Review of Social Identity}

concerned with reducing this uncertainty. According to GEM, national identification mediates the relationship between procedural justice and compliance. According to GVM, procedural justice reduces resistance to citizens with high national identification. According to UMM, procedural justice reduces disengagement among citizens with low national identification. This indicates that compliance $\&$ defiance are multiaspect, hence the effect of procedural justice can have different mechanisms. Police justice is more effective in reducing non-compliance than increasing compliance in citizens with low national identification, but is equally effective in influencing both in citizens with high national identification.

The study for the third reason examines the effect of police procedural justice (when dealing with citizens in preventing terrorism cases) on the willingness of Muslims to cooperate by reporting suspected terrorists. Procedural justice did increase national identification (Madon et al., 2017; Murphy et al., 2018) and perceptions of police legitimacy. Procedural justice also predicted intention to cooperate with the police, albeit mediated by legitimacy (Madon et al., 2017). Murphy et al. (2018) found partial mediation by social inclusion (feelings of being accepted and valued by society) but the effect was relatively small. Meanwhile, the moderating effect was stronger: Procedural justice increased the intention to cooperate especially in Muslims with low social inclusion scores. Referring to UMM, Muslims who felt they belonged to the 'suspected community' felt uncertain about their status, thus were less willing to cooperate with the police.

\section{Mass Policing}

To the best of our knowledge there have been three studies on mass policing. Stott et al. (2011) applied GEM, PBRM, and ESIM (Elaborated Social Identity Model) in an ethnographic study of mass policing of football fans in England. ESIM is a SIT-based model which assumes that mass action riots are caused by an identity change in relation to the police, due to the homogeneous and offensive treatment from the police (Drury \& Reicher, 2009). Initially, the masses had a heterogeneous identity (most wanted peaceful action, some were radical) but since the police saw the masses as a threat and reacted indiscriminately, the masses felt a unified identity as protesters (ingroup) against the police (outgroup). Researchers conducted participatory interviews and observations of local police and conflicting fans. Researchers also communicated intensely with the police to apply strategic approach based on the theory. Apparently, the perceived police legitimacy increased after a lot of dialogue with fans. Fans began to view the police as an ingroup and worked together to prevent conflicts between clubs. This study proves the role of police treatment and legitimacy, but emphasizes the role of relational rather than national identification for cooperation.

Radburn and Stott (2018) conducted an experiment on the general public (study 1) and fans of two conflicting football clubs (study 2) in the UK to determine the effect of social categories on procedural justice judgment, relational identification, identification with the community (subject to interpretation), and intentions to cooperate with the police during clashes between police and the masses. The participants were showed a video of confrontation between police \& demonstrators, wherein both parties attacked each other so that the one at fault was open to interpretation. The 


\section{Larasati et al || Literature Review of Social Identity}

manipulated social categories of demonstrators based on ideological groups (study 1) and football club fans (study 2) affected procedural justice, relational identification, perceived community identity prototypicality ("The police in the video act like role models in my community"), and perceived community identity advancement ("Police act like champions for my community"). The police were considered more fair and representing the ingroup if the one being policed was an outgroup. Procedural justice thus predicted relational identification and cooperative intentions, but there was no mediating effect of relational identification. Community identification was not predicted by procedural justice, predicted negatively (study 1) and did not predict (study 2) cooperation, indicating that the salient category at that time was not citizens.

Urbanska et al. (2019) found similar results in a study of Northern Ireland residents, in the form of experiment 2 (Target: ingroup vs. outgroup; between-subject) x 2 (Police treatment: facilitative vs. restrictive, within-subject). Participants read fictitious cases about ingroups or outgroups being drunk on the streets during a parade. It turns out that the preferrable police treatment of the target group was largely determined by the attitude towards the outgroup: A negative attitude triggered an intergroup bias (considering that restrictive treatment in the outgroup \& facilitative treatment in the ingroup is fairer). Positive attitude towards outgroup and perceived police legitimacy predicted acceptance \& perceived justice from restrictive police treatment, both to ingroup and outgroup. In areas with a history of horizontal conflict, negative intergroup sentiment was associated with perceived authority favoritism towards certain groups (Urbanska \& Guimond, 2018). There was no significant effect of community identification. Thus, GEM and GVM are less supported in the context of mass policing.

\section{Support for Economic Equality}

Tassinari and Jasinskaja-Lahti (2020) conducted a survey of Italian society to examine the effect of procedural justice of Italian, European Union and world authorities on the support of economic equality, as well as mediation by group identification. In all three levels, procedural justice predicted group identification positively, but negatively predicted support for economic equality. Group identification also did not predict support for economic equality. The researcher argued that the perceived fairness of authority coupled with high group identification can be a double-edged sword for minorities, as it makes people more inclined to accept the status quo (system justification) and reduces the need to confront injustice.

\section{Synthesis}

Procedural justice theories in this article (GVM, GEM, and PBRM) has obtained a lot of empirical evidence. However, it must be acknowledged that there is a lack of evidence for their application in different contexts. GVM and GEM with their explanation of identity have been successful in various previous and recent studies, especially in the organizational context. Abroad and in Indonesia, the model's assumptions were widely supported in the context of organizations such as industry (Yulianti, 2016), state institutions (Tjahjono et al., 2020), and political parties (Maulana \& Faturochman, 2007). Studies in the national context are relatively few and the results are inconsistent. Referring to GEM, 
all studies define procedural justice as a fair decision-making process (instrumental) and treatment (relational) from authorities. All studies support the premise that procedural justice judgment affects compliance/cooperation with authority, except for the study by Tassinari and Tassinari and Jasinskaja-Lahti (2020) where procedural justice was negatively related to support for economic equality. The author suspects that since 'equality' in the survey was an abstract idea instead of an explicit policy of authority, it did not necessarily represent cooperation with authority. Other studies examined explicit compliance/cooperation, hence the impact of procedural justice is evident.

Although procedural justice has a consistent effect, this is not the case with the role of group identification which is a key variable in social identity-based procedural justice theory. The initial study by T. Tyler et al. (1996) found that the explanatory power of the model differs for different contexts. Although social identity mediation was evident in all contexts (family, company, university, country), the model proved strongest in the family context and weakest in the country context. According to the researchers, this is caused by two factors. First, compared to authority in other contexts, parents are most easily identified as the authority that represents the family. Courts are not necessarily perceived as salient representative authorities of the state, at least at the time of the study. Second, the frequency of experience with the highest authority in the family context. Respondents in the study had never experienced direct interaction with the court, so that treatment and unfair decisions from parents were considered more meaningful than those of judges in court. However, GEM was claimed to be applicable in various contexts including state (T. R. Tyler, 2009; T. R. Tyler \& Blader, 2003) although there are pros and cons regarding the role of group identification in this context. The relevant issues will be discussed in the following sections.

\section{Currently Salient Category}

The impact of procedural justice of state authorities on citizen compliance/cooperation is not always mediated by national identification. Referring to self-categorization theory (SCT), social identity is a collective self-representation that is highly dependent on the dynamic and historical intergroup context (Drury \& Reicher, 2009). Thus, the active social identity in a person can change depending on the context of intergroup interaction. The identity that is considered in theory and research is a relatively fixed and abstract superordinate category (Radburn \& Stott, 2018). In fact, the identity is not always salient. Researchers often overlook the multidimensional nature of social identity: the many other social categories an individual belongs to (e.g. political affiliation, football fan) also influence his perception of the authority fairness. Which social category is salient at any one time can be influenced by the following.

The Behavior under Study. Thus far, findings that consistently support GEM are in the context of legal compliance, such as a history of law violation (T. R. Tyler, 2009), tax (Hartner et al., 2008; Hartner-Tiefenthaler et al., 2013; Murphy et al., 2015) and traffic rules compliance (Bradford et al., 2015). In this context, the participant's identity as a citizen is arguably salient, because the behavior has a direct impact on the state and fellow citizens (not just authority). Paying taxes is needed for public welfare (assuming that participants understand tax literacy), obeying traffic rules is needed so 


\section{Larasati et al || Literature Review of Social Identity}

as not to harm other citizens. In contrast to cooperation in preventing/eradicating crime which is the main task of the police, paying taxes is a very prototypical form of obligation to the group, as it is considered positive and agreed upon by the group (T. R. Tyler \& Blader, 2003). Moreover, social dilemma clearly occurs in the context of paying taxes: Taxes burden the individual, but development would stop had no one paid taxes (Gangl et al., 2015). Group identification has been shown to predict cooperative behavior towards groups (Brewer, n.d.). When the group becomes an important part of the self-concept, the group's goals are also considered important.

In the context of Muslim cooperation in preventing terrorism, mediating effect of group identification in the effect of procedural justice on cooperation was weak (Murphy et al., 2019) or insignificant (Madon et al., 2017). Instead, police legitimacy was the stronger mediator in these studies. The author argued that national identity is not always salient in terrorism prevention behavior. Terrorism is a humanitarian problem that also tarnishes the image of religion (Yildiz \& Verkuyten, 2012) so that it could go beyond the issue of rebellion against the state. Although procedural justice increases national identification, Muslim citizens do not have to have high national identification to be willing to cooperate in combating terrorism. Moral attitudes related to terrorism (unfortunately not examined in the study) coupled with perceived police legitimacy may better predict the intention to cooperate.

The role of group identification also did not appear in the context of mob policing, where the researcher examines the antecedents and impact of procedural justice judgment in cases involving outgroup or ingroup mobs. In this context, police procedural justice judgments are determined by outgroup attitude (Urbanska et al., 2019) or even simply by manipulating the social categories of policing targets (Radburn \& Stott, 2018). Procedural justice judgments then predict intention to assist police (Radburn \& Stott, 2018) and acceptance of police decisions (Urbanska et al., 2019). The authors argued that in these studies, the ingroup vs. outgroup conflict was more salient than the superordinate group (the state). The behavior of the policing target in these studies was made ambiguous, allowing the influence of ingroup bias in which problems are attributed to outgroup faults (Ruback \& Singh, 2007). This finding reminds us of the relative importance of instrumental aspect (acceptance of a decision, for example the arrest of the guilty party) over non-instrumental aspect (the quality of treatment of the authorities) in the context of disputes (T. R. Tyler, 1989). Apparently disputes occur not only at the interpersonal level, but also at the intergroup level.

Categories Represented by State Authorities. The second issue relates to the assumption that all state authorities must be prototypical or represent the state, while state is itself an abstract and superordinate category. In some contexts, authority is more clearly seen as representing the group. For example, in the organizational context, the treatment from managers/supervisors is closely related to the company's attitude in general, so that unfair treatment from the authorities has a stronger impact on perceived status of the employee. Likewise, procedural justice judgment from governments in general (T. R. Tyler, 2009) or tax authorities (Murphy et al., 2015). Perceptions of these two institutions can be abstract and impersonal since there are relatively few direct interactions with individuals or community groups. Moreover, Tyler studied in a transitional situation when political institutions and policies were still unstable and constantly under public scrutiny. Meanwhile, the police who interact 


\section{Larasati et al || Literature Review of Social Identity}

more directly with the public do not always represent the state in a salient manner, at least during research or interaction. The police can also be seen as a separate individual or social category (Radburn \& Stott, 2018). This shows the importance of prototypicality or how much authority represents a group (Hogg, 2001) which ironically is rarely measured (except (Radburn \& Stott, 2018).

In the case of mass policing (involving one or more community groups), the police can be seen as a separate social category depending on the context of intergroup interaction. For example, protestors who were initially anti-violence saw rioters as an 'outgroup'. However, when the police feel threatened and attack the masses indiscriminately, the rioting protestors are then considered 'ingroup' while the police are considered 'outgroup' (Stott et al., 2011). In mass policing experiments (Radburn \& Stott, 2018; Urbanska et al., 2019), the group being targeted by the police was relevant to the participants (as ingroup/outgroup). Due to salient intergroup context, the police were seen as a third party who is expected to represent the ingroup (as indicated by perceived community identity prototypicality and advancement). In this case, identity may influence perceived procedural justice: Objectively fair procedures do not greatly enhance perceptions of justice when the outcomes threaten group identity important to the individual (Mayer et al., 2009). This subjective perception affects relational identification built on the relationship between citizens and the police (as a separate category) instead of the 'state'. Justice is not only about state representation, but also taking sides with communities that are important to citizens.

In the case of individual policing, the police are not necessarily considered to represent the state. This is thought to influence the absent mediation of community identification in the study of Pehrson et al. (2017). There are several possible explanations. The researchers argued that in the context of police-citizens relationship, police actions may have more impact on the exclusive status of the police than on the status of citizens themselves. The injustice of the police doesn't necessarily make citizens stop considering themselves as citizens, but they may stop considering the police as the representative authority of the state. This argument has implications for the need to control the prototypical state of the police. However, as in the case of mass policing, there is also the possibility of intergroup mechanisms: Northern Ireland as the study site has a history of conflict between Catholic and Protestant communities and between communities and the police. In such areas, the police can also be perceived as an institution that favors the outgroup over ingroup (Urbanska \& Guimond, 2018) so that relational identification becomes relevant. Relational identification can also be based on interpersonal relationships with the police as 'individuals', especially for those who are in frequent contact with the police. This is evident in the greater mediating effect of relational over national identification in the relationship between police procedural justice and intention to cooperate in the homeless and immigrants (Kyprianides et al., 2021; Sargeant et al., 2020).

\section{The Role of Legitimacy}

Referring to PBRM, perceived legitimacy of authority could also mediate the effect of procedural justice on compliance/cooperation (Sunshine \& Tyler, 2003; T. R. Tyler \& Huo, 2002). Perceived legitimacy was found as a mediator (Murphy et al., 2015) or even the sole mediator of the effects 
of procedural justice on compliance/cooperation (Madon et al., 2017; Pehrson et al., 2017). In another study, perceived legitimacy was predicted by procedural justice via national identification (Bradford et al., 2015; Bradford et al., 2016; Bradford et al., 2014) and mediated national identification with compliance/cooperation (Bradford et al., 2014; Kyprianides et al., 2021). The definition of legitimacy in each study is different, but the majority include a sense of obligation to obey the police as the competent authority. Bradford et al. (2014) argued that the relationship between procedural justice and cooperation has two aspects: affective (feelings of inclusion and attachment to the group, underlying the role of identification) and evaluative (perception that authority is legal and must be obeyed, underlying the role of legitimacy). Procedural justice shows that the police have good goals (goal alignment) and act within the bounds of authority (bounded authority) so as to trigger positive feedback from citizens (Pehrson et al., 2017). Police involvement that is considered to exceed the limit will reduce legitimacy regardless of the fairness of the procedure (Trinkner et al., 2018).

Interestingly, the relative importance of the role of legitimacy or identification could differ for each community group. Bradford et al. (2014) found that residents who are also British citizens were more motivated to cooperate with the police by legitimacy judgment (evaluative), while non-British citizens were more motivated by a sense of belongingness in the UK (affective). In contrast to the general population, the effect of procedural justice on the homeless' cooperation in UK was not mediated by legitimacy but rather by national and relational identification (Kyprianides et al., 2021). This supports the argument of (T. R. Tyler \& Blader, 2003): The social identity mechanism is important for members who have the need for identity security in the group. However, the role of identification was not as big as legitimacy when the national identity was less salient as in terrorism prevention studies (Madon et al., 2017; Pehrson et al., 2017). Thus, the effect of legitimacy outweighs national identification when the national category is less salient or the need for identity security is low.

As a side note, legitimacy is not the only alternative mechanism. Macro processes in a country allow for other factors that might have a greater influence on citizen cooperation and compliance. Many studies that tested the theory of procedural justice were conducted in Western countries which are relatively democratic and have low crime rates (Roche \& Oberwittler, 2018). These studies examined the role of interactional factors aka micro-scale interactions with the police (including police procedural justice judgment) in predicting cooperation/compliance. However, in Nigeria and Japan where the rate of lawlessness (including by the police) is high, cooperation and legitimacy were more predicted by instrumental factors (perceived police effectiveness against crime) rather than perceived justice. Thus, institutional and macro-scale factors such as trust in government and political systems, perceptions of corruption, and level of security determine the relative importance of instrumental factors in predicting cooperation/compliance. Given that Indonesia has a relatively high crime rate in Southeast Asia (Asmardika, 2020), researchers should measure instrumental factors as alternative predictors. 


\section{Larasati et al || Literature Review of Social Identity}

\section{What Groups Mean to Individuals: Moderation of National E Ethnic Identification}

In some cases, the effect of procedural justice is greater on citizens with certain characteristics. GVM argues that procedural justice becomes a greater concern to members who feel the relevance of their group identity (T. R. Tyler \& Lind, 1992). This can be interpreted in two versions: (1) Procedural justice is more important for those who feel included in the group i.e. have high group identification (Huo et al., 1996); (2) Procedural justice is more important to the marginalized, as they feel uncertain of their status in the superordinate group (Cremer \& Sedikides, 2005). Studies generally refer to the first version: Procedural justice is assumed to have more impact on citizens with high national identification (Bradford et al., 2014; Sargeant et al., 2020; Wenzel, 2002), low ethnic identification (Murphy, 2013), or perceived high social inclusion (Murphy et al., 2018). However, it should be noted that the relationship between national and ethnic identification is inconsistent. National identification in Australia was positively (Murphy, 2013) and negatively (Bradford et al., 2014) associated with ethnic identification. According to common ingroup identity model, minority groups can have a dual identity or high national and ethnic identification (Ramiah et al., 2011). Citizens can also have high ethnic identification and low national identification, especially if they have a history of vertical conflicts such as supporters of Catalan (Serrano, 2013) and West Papuan separatism (Murphy et al., 2018).

Only Wenzel's study fully supports the first interpretation: Procedural justice reduced non-compliance with paying taxes (especially blatant violations that are easily traceable) in citizens with high national identification. Findings of Sargeant et al. (2014). partially support that procedural justice reduces resistance (acceptance of police authority, but rejection of their use of power) only in citizens with high national identification. Identification did not moderate the effect of procedural justice on motivation to comply with the police (commitment \& capitulation). It did moderate the effect of procedural justice on disengagement (complete rejection of the police \& the current legal system) albeit in the opposite direction (only in citizens with low national identification). Researchers suspect that there is a direct influence of national identification on citizens' compliance and non-compliance, where citizens with high identification tend (or are easier) to be more obedient. Meanwhile, citizens with low national identification tend to 'turn a blind eye' to the procedural justice of authority if their decision is detrimental to themselves or their group (Mayer et al., 2009).

Other studies examining the impact of procedural justice on legitimacy (Bradford et al., 2014; Murphy, 2013) and cooperation (Bradford et al., 2014; Murphy et al., 2018) further support the second interpretation of GVM. Procedural justice predicts trust in the police only in minority citizens with high ethnic identification (Murphy, 2013).

In longitudinal studies, the effect of procedural justice on legitimacy was less important for citizens who initially had high ethnic identification (Bradford et al., 2014). However, increased ethnic identification was associated with increased perceived legitimacy, suggesting that being identified with any group triggers perceptions of anomie. An exception was the effect of police procedural justice when testing alcohol consumption on legitimacy, which was not moderated by national identification (Sargeant et al., 2014). Procedural justice predicts cooperation, especially among non-UK residents (mediated by sense of belongingness; Bradford et al. (2014) and Muslims who feel excluded (Murphy 
et al., 2018). In line with UMM, minorities' uncertainty of their status in the superordinate group encourages certainty seeking through procedural justice.

It is noteworthy that when there is a history of vertical conflict (between certain groups and the government), the effect of procedural justice might not only be moderated by ethnic identification which does not necessarily imply the need to secure national identity. Especially in the context of separatism, national identity is not always considered meaningful for ethnic minorities. The effect of procedural justice on cooperation is also influenced by perceived subordination (colonization) by the majority group. In a study of Papuan separatism, ethnic identification and especially perceived subordination by Indonesia predicts perceived identity subversion (that values/norms are dominated by the majority group, underestimating the essence of minority groups) and perceived majority injustice, which in turn reduces national identification and reconciliation attitudes (Mashuri \& van Leeuwen, 2017). In this case, the impact of procedural justice on cooperation may be greater for minority groups with high ethnic identification and perceived subordination. Ethnic identification alone is not necessarily enough to moderate, because citizens can have a dual identity that actually predicts trust and cooperation (Ramiah et al., 2011). However, this does not eliminate the need to secure identity: Perceived government injustice negatively predicts the national identification of Papuans. Thus, GVM could be applied to studies involving minority groups, but perceived subordination is an important moderator in the context of vertical conflict.

\section{Conclusion}

GEM and GVM have proven their explanatory power in organizational context. However, there are issues that need to be considered if both models are to be applied in the national context, given its very broad scope. The affective mechanism in intergroup dynamics (i.e. national identification) as emphasized by the model is sometimes limited by which social category is being salient. GEM was consistently supported by studies on legal compliance (breaking the law, paying taxes, and obeying traffic laws) involving salient state authorities, namely the government (T. R. Tyler, 2009) and tax authorities (Hartner et al., 2008; Murphy et al., 2015). GEM was not supported in the context of terrorism prevention and mass policing. Assessment of the police justice was also influenced by the direct interaction of the police with individuals/groups at one time. As a result, national identity may be less salient than human identity (in the case of terrorism) and identity associated with the groups being policed (e.g. ideological groups or football club fans). In such studies, researchers should examine perceived legitimacy and relational identification with the police as significant potential mediators. Given that police are not always considered to be representative of the state, researchers should also control for the state/community identity prototypicality (Radburn \& Stott, 2018).

In the context of mass policing and the history of vertical and horizontal conflicts, researchers need to pay more attention to the intergroup dynamics. The social identity approach to procedural justice arises out of dissatisfaction with the reductionist individualist approach (individual instrumental motives) and the greater focus on group processes (T. R. Tyler, 1989; T. R. Tyler \& Blader, 


\section{Larasati et al || Literature Review of Social Identity}

2003). Ironically, studies with this approach are more individual-oriented: examining the relationship between police and citizens at the interpersonal rather than intergroup level (Radburn \& Stott, 2018). Whereas horizontal conflicts can make procedural justice judgment (and thus intention to cooperate) influenced by intergroup sentiments (Radburn \& Stott, 2018; Urbanska et al., 2019). Studies in this context need to control attitudes towards outgroups, especially if the conflict has involved the police (Pehrson et al., 2017).

In studies of minority groups, procedural justice has greater impact on citizens with low national identification and high ethnic identification due to uncertainty and the need to secure identity. Under the same assumptions, the mediating effect of national identification should be stronger than that of legitimacy. To strengthen this assumption, researchers need to explicitly measure the uncertainty of citizenship status. In the context of vertical conflict, researchers also need to control the perception of state subordination.

As social identity-based theories, GEM and GVM are highly context-bound. Researchers are suggested to pay attention to the aforementioned issues and consider alternative mechanisms (e.g. perceptions of police legitimacy and effectiveness). Despite their limitations, overall GEM and GVM are supported by the majority of studies in this review. Studies on police compliance/cooperation in general, for example, find mediating national identification in the effects of procedural justice on perceived legitimacy (Bradford et al., 2016; Bradford et al., 2014) and cooperation (Bradford et al., 2014). In the future, researchers need to test the strength of this model using longitudinal surveys and experiments. So far the authors have found only 3 experiments (Radburn \& Stott, 2018; Sargeant et al., 2014; Urbanska et al., 2019) and two longitudinal surveys (Bradford et al., 2014; Murphy et al., 2015) in the national context. Of these studies, only Radburn and Urbanska's study did not support GEM because of the prominent context of intergroup conflict.

Longitudinal surveys are urgently needed considering that group identification can mediate as well as moderate. It is possible that in the context of long-term terrorism prevention, national identification could also have a mediating effect. Ethnographic studies (Stott et al., 2011) are also important in examining conflicts between the police and certain community groups.

Procedural justice theories are still relevant to the current socio-political situation, especially in a country that is never devoid of compliance issues. For example, a fifth of Indonesians violated health protocols during the pandemic (Tim BPS Covid-19 Statistical Task Force, n.d.). 55\% reasoned that there were no sanctions (instrumental factor), but 19\% reasoned that the leaders and government failed to set a good example. This indicates the influence of procedural justice judgment (e.g. inconsistent rule enforcement) on cooperation, directly or indirectly (through perceived legitimacy). Likewise, radicalism can depart from perceived government injustice (Nurjannah, 2013). However, other identity factors are also worth considering. For example, support for non-democratic policies in Indonesia was influenced by identification with political parties and figures who endorse them (Fossati et al., 2021). Researchers thus could conduct experiments that manipulate social categories (e.g. political party supporters). Ethnographic studies can be applied in cases of protests, riots between football fans and among students that occur frequently. In short, Indonesia is a fertile ground for procedural 


\section{Larasati et al || Literature Review of Social Identity}

justice studies, which unfortunately are still limited. Studies in the national context were dominated by taxation topics, all of which did not examine the role of national identification. This also unveils the limitation of this article as it mostly discusses foreign studies. Nevertheless, it is meant to provide references and encourage Indonesian academics to do more research on procedural justice, which is always relevant in the life of the state.

\section{Declarations}

\section{Author Contribution}

All authors contributed to the conceptualization and methodology. Literature collection, analysis, synthesis, and preparation of the initial manuscript were carried out by AML. JH and HM provided literature resources, provided critical input on the synthesis and writing of the manuscript, read and approved the final manuscript.

\section{Conflict of Interest Statement}

The author declares that there is no conflict of interest in the writing of this article.

\section{Orcid ID}

Andina Mega Larasati https:/ / orcid.org/0000-0001-9982-1084

Joevarian Hudiyana https:/ / orcid.org/0000-0001-5507-0573

Hamdi Muluk https:/ / orcid.org/0000-0002-9400-3055

\section{References}

Asmardika, R. (2020). Qatar negara teraman di dunia pertengahan 2020, indonesia peringkat 76 [qatar is the safest country in the world mid-2020, indonesia in the 76th rank]. www.news.okezone. com

Blader, S. L., \& Tyler, T. R. (2009). Testing and extending the group engagement model: Linkages between social identity, procedural justice, economic outcomes, and extrarole behavior. Journal of Applied Psychology, 94(2), 445-464. https://doi.org/10.1037/a0013935

Bradford, B., Hohl, K., Jackson, J., \& MacQueen, S. (2015). Obeying the rules of the road. Journal of Contemporary Criminal Justice, 31(2), 171-191. https:// doi.org/10.1177/1043986214568833

Bradford, B., Martin, R., Garcia-Anon, J., Garcia Saez, J., \& Ferreres, A. (2016). Instrumental and affective influences on public trust and police legitimacy in spain. European Journal of Policing Studies, 3(4), 394-416.

Bradford, B., Murphy, K., \& Jackson, J. (2014). Officers as mirrors. British Journal of Criminology, 54(4), 527-550. https://doi.org/10.1093/bjc/azu021 


\section{Larasati et al || Literature Review of Social Identity}

Braithwaite, V. (2009). Defiance in taxation and governance: Resisting and dismissing authority in a democracy. Edward Elgar Publishing.

Brewer, M. B. (n.d.). Intergroup discrimination: Ingroup love or outgroup hate? In C. G. Sibley \& F. K. Barlow (Eds.), The cambridge handbook of the psychology of prejudice (pp. 90-110). Cambridge University Press. https:/ / doi.org/10.1017/9781316161579.005

Cremer, D. D., \& Sedikides, C. (2005). Self-uncertainty and responsiveness to procedural justice. Journal of Experimental Social Psychology, 41(2), 157-173. https:/ / doi.org/10.1016/j.jesp.2004.06.010

Davies, S. G., Meliala, A., \& Buttle, J. (2014). Gangnam style versus eye of the tiger: People, police and procedural justice in indonesia. Policing and Society, 26(4), 453-474. https:/ / doi.org/10.1080/ 10439463.2014.949712

Drury, J., \& Reicher, S. (2009). Collective psychological empowerment as a model of social change: Researching crowds and power. Journal of Social Issues, 65(4), 707-725. https: / / doi.org / 10. $1111 /$ j.1540-4560.2009.01622.x

Faturochman. (2002). Pustaka Pelajar.

Faturochman, \& Ancok, D. (2001). Dinamika psikologis penilaian keadilan [The psychological dynamic of justice evaluation]. Jurnal Psikologi, 1(1), 41-60.

Faturochman, \& Walgito, B. (2002). Ketidakberdayaan pemilik sawah dan ketidakadilan terhadap mereka: Kasus penanaman tembakau di klaten [the helplessness of field owners and injustice towards them: The case of tobacco planting in klaten]. Populis, 13(1), 67-92.

Fossati, D., Muhtadi, B., \& Warburton, E. (2021). Why democrats abandon democracy: Evidence from four survey experiments. Party Politics. https://doi.org/10.1177/1354068821992488

Gangl, K., Hofmann, E., \& Kirchler, E. (2015). Tax authorities textquotesingle interaction with taxpayers: A conception of compliance in social dilemmas by power and trust. New Ideas in Psychology, 37, 13-23. https://doi.org/10.1016/j.newideapsych.2014.12.001

Hanifah, H., \& Yudianto, I. (2019). The influence of religiosity, nationalism, and tax corruption perception on tax compliance: Study of the micro, small and medium enterprises (msmes) taxpayers in bandung city. Journal of Accounting Auditing and Business, 2(1), 17. https: / / doi. org/10.24198/jaab.v2i1.20428

Hartner, M., Rechberger, S., Kirchler, E., \& Schabmann, A. (2008). Procedural fairness and tax compliance. Economic Analysis and Policy, 38(1), 137-152. https: / / doi.org / 10.1016/s03135926(08)50010-5

Hartner-Tiefenthaler, M., Rechberger, S., \& Kirchler, E. (2013). Justice perceptions and cooperation of citizens with the tax-authorities: The group engagement model of cooperation. Citizenship Teaching \& Learning, 8(2), 179-193. https://doi.org/10.1386/ctl.8.2.179_1

Hogg, M. A. (2001). A social identity theory of leadership. Personality and Social Psychology Review, 5(3), 184-200. https://doi.org/10.1207/s15327957pspr0503_1

Hogg, M. A., \& Abrams, D. (1988). Social identifications: A social psychology of intergroup relations and group processes. Taylor \& Frances/Routledge. 


\section{Larasati et al || Literature Review of Social Identity}

Huo, Y. J., Smith, H. J., Tyler, T. R., \& Lind, E. A. (1996). Superordinate identification, subgroup identification, and justice concerns: Is separatism the problem; is assimilation the answer? Psychological Science, 7(1), 40-45.

Kuncoro, M. W. (2001). Penilaian keadilan prosedural ditinjau dari penilaian keadilan interaksional dan kontrol pada para korban gempa bumi di bantul [assessment of procedural justice analysed from the evaluation of interactional justive and control on the victims of earthquake in bantul], 1-7.

Kyprianides, A., Bradford, B., Jackson, J., Yesberg, J., Stott, C., \& Radburn, M. (2021). Identity, legitimacy and cooperation with police: Comparing general population and a london street population. http://eprints.lse.ac.uk/id/eprint/108997

Leventhal, G. S. (1980). What should be done with equity theory? In Social exchange (pp. 27-55). Springer US. https:/ / doi.org/10.1007/978-1-4613-3087-5_2

Lind, E. A. (2001). Fairness heuristic theory: Justice judgments as pivotal cognitions in organizational relations. In Advances in organizational justice (pp. 56-88).

Lind, E. A., \& Tyler, T. R. (1988). Introduction. In The social psychology of procedural justice (pp. 1-6). Springer US. https://doi.org/10.1007/978-1-4899-2115-4_1

Madon, N. S., Murphy, K., \& Cherney, A. (2017). Promoting community collaboration in counterterrorism: Do social identities and perceptions of legitimacy mediate reactions to procedural justice policing? British Journal of Criminology, 53. https: / / doi.org/10.1093 / bjc / azw053

Mashuri, A., \& van Leeuwen, E. (2017). Predicting support for reconciliation in separatist conflict. Personality and Social Psychology Bulletin, 44(2), 173-185. https : / / doi . org / 10 . 1177 / 0146167217733076

Maulana, H., \& Faturochman. (2007). Gaya kepemimpinan transformasional dan penilaian keadilan prosedural pada partai politik berbasiskan ideologi nasionalisme dan religius [transformational leadership style and procedural justice assessment in political parties based on nationalism and religious ideology]. Indigenous, 9(2), 37-53. https: / /journals.ums.ac.id / index.php/indigenous/article/view/4711

Mayer, D. M., Greenbaum, R. L., Kuenzi, M., \& Shteynberg, G. (2009). When do fair procedures not matter? a test of the identity violation effect. Journal of Applied Psychology, 94(1), 142-161. https: //doi.org/10.1037/a0013108

Muluk, H., \& Budiarti, T. (2008). Keadilan dalam konteks dominansi sosial dan kepercayaan [Justice in the context of social and belief dominance]. Jurnal Psikologi Sosial, 13(1), 41-54.

Murphy, K. (2013). Policing at the margins: Fostering trust and cooperation among ethnic minority groups. Journal of Policing, Intelligence and Counter Terrorism, 8(2), 184-199. https://doi.org/10. 1080/18335330.2013.821733

Murphy, K., Bradford, B., \& Jackson, J. (2015). Motivating compliance behavior among offenders. Criminal Justice and Behavior, 43(1), 102-118. https:/ / doi.org/10.1177/0093854815611166 


\section{Larasati et al || Literature Review of Social Identity}

Murphy, K., Cherney, A., \& Teston, M. (2018). Promoting muslims' willingness to report terror threats to police: Testing competing theories of procedural justice. Justice Quarterly, 36(4), 594-619. https://doi.org/10.1080/07418825.2018.1437210

Murphy, K., Cherney, A., \& Teston, M. (2019). Promoting muslims willingness to report terror threats to police: Testing competing theories of procedural justice. Justice Quarterly, 36(4), 594-619. https://doi.org/https://doi.org/10.1080/07418825.2018.1437210

Nurjannah. (2013). Faktor pemicu munculnya radikalisme islam atas nama dakwah [triggering factors of the arise of islam radicalism in the name of dakwah]. Jurnal Dakwah, 14(2), 177-198.

Nurpratiwi, D. H. (2017). Hubungan persepsi keadilan distributif dan keadilan prosedural dengan tingkat kepercayaan masyarakat pada polisi republik indonesia [the correlation between perception of distributive justice and procedural justice with the level of public trust in the national police of the republic of indonesia] (Doctoral dissertation). Universitas Islam Sultan Agung.

Pehrson, S., Devaney, L., Bryan, D., \& Blaylock, D. L. (2017). Beyond group engagement: Multiple pathways from encounters with the police to cooperation and compliance in northern ireland. PLOS ONE, 12(9), e0184436. https:/ / doi.org/10.1371/journal.pone.0184436

Purnamasari, A., Pratiwi, U., \& Sukirman, S. (2018). Pengaruh pemahaman sanksi perpajakan tingkat kepercayaan pada pemerintah dan hukum serta nasionalisme terhadap kepatuhan wajib pajak dalam membayar pbb-p2 (studi pada wajib pajak pbb-p2 di kota banjar) [the effect of understanding in tax penalty, trust in government and law order, and nationalism towards the adherence of taxpayer in paying pbb-p2 (a study on taxpayer of pbb-p2 in banjar city)]. Jurnal Akuntansi dan Auditing, 14(1), 22. https:/ / doi.org/10.14710/jaa.v14i1.18221

Putong, I. H. (2017). Kepatuhan wajib pajak orang pribadi: Peran kepercayaan kepada pemerintah, keadilan prosedural cerapan dan persepsi atas perilaku wajib pajak lain (studi eksperimen pengusaha umkm) [the adherence of personal taxpayer: The role of trust in government, observed procedural justice, and perception towards behavior of other taxpayers (an experimental study of micro-and-middle business owners)] (Doctoral dissertation). Universitas Airlangga.

Radburn, M., \& Stott, C. (2018). The social psychological processes of 'procedural justice': Concepts, critiques and opportunities. Criminology \& Criminal Justice, 19(4), 421-438. https: / /doi.org/10. $1177 / 1748895818780200$

Ramiah, A. A., Hewstone, M., \& Schmid, K. (2011). Social identity and intergroup conflict. Psychological Studies, 56(1), 44-52. https:/ / doi.org/10.1007/s12646-011-0075-0

Ratmono, D. (2014). Model kepatuhan perpajakan sukarela: Peran denda, keadilan prosedural, dan kepercayaan terhadap otoritas pajak [model of tax compliance: The role of fine, procedural justice, and trust in tax authorities]. Jurnal Akuntansi \& Auditing Indonesia, 18(1), 42-64. https: //doi.org/10.20885/jaai.vol18.iss1.art4

Roche, S., \& Oberwittler, D. (2018). Towards a broader view of police-citizen relations: How societal cleavages and political contexts shape trust and distrust, legitimacy and illegitimacy. In Police-citizen relations across the world: Comparing sources and contexts of trust and legitimacy (pp. 3-26). London, Routledge. 


\section{Larasati et al || Literature Review of Social Identity}

Rosana, F. C. (2020). 4 hal tentang demo aksi 1812 hari ini, tuntut rizieq bebas hingga omnibus law [4 things about today's 1812 demonstration, demand that rizieq be free to the omnibus law]. https: / / metro.tempo.co / read / 1415555 / 4-hal-tentang-demo-aksi-1812-hari-ini-tuntutrizieq-bebas-hingga-omnibus-law

Ruback, R. B., \& Singh, P. (2007). Ingroup bias, intergroup contact and the attribution of blame for riots. Psychology and Developing Societies, 19(2), 249-265. https: / / doi . org / 10.1177 / 097133360701900206

Sargeant, E., Antrobus, E., Murphy, K., Bennett, S., \& Mazerolle, L. (2014). Social identity and procedural justice in police encounters with the public: Results from a randomised controlled trial. Policing and Society, 26(7), 789-803. https://doi.org/10.1080/10439463.2014.989159

Sargeant, E., Davoren, N., \& Murphy, K. (2020). The defiant and the compliant: How does procedural justice theory explain ethnic minority group postures toward police? Policing and Society, 31(3), 283-303. https:/ / doi.org/10.1080/10439463.2020.1720016

Serrano, I. (2013). Just a matter of identity? support for independence in catalonia. Regional \& Federal Studies, 23(5), 523-545. https:/ / doi.org/10.1080/13597566.2013.775945

Stott, C., Hoggett, J., \& Pearson, G. (2011). Keeping thep peace: Social iidentity, procedural justice and the policing of football crowds. British Journal of Criminology, 52(2), 381-399. https: / / doi.org/ $10.1093 / \mathrm{bjc} / \mathrm{azr} 076$

Sunshine, J., \& Tyler, T. R. (2003). The role of procedural justice and legitimacy in shaping public support for policing. The law \& Society Review, 37(3), 513-548. https:/ / doi.org/10.1111/15405893.3703002

Tassinari, M., \& Jasinskaja-Lahti, I. (2020). Perceived procedural justice, group identification, and support for economic equality: A test of the group engagement model. University of Salento. https://doi.org/10.1285/I24212113V6I2-1P56

Thibaut, J., Walker, L., Latour, S., Houlden, P., Stanford, S., Review, L., Law, S., \& Latour, S. (1974). Procedural justice as fairness. Stanford Law Review, 26(6), 1271-1289. https:/ / doi.org/10.2307/ 1227990

Tim BPS Covid-19 Statistical Task Force. (n.d.). Hasil survei perilaku masyarakat di masa pandemi covid-19 (7-14 september 2020) [survey results of public behavior in covid-19 pandemic (7-14 september 2020)]. Jakarta, Badan Pusat Statistik.

Tjahjono, H. K., Rahayu, M. K. P., \& Putra, A. D. (2020). The mediating role of affective commitment on the effect of perceived organizational support and procedural justice on job performance of civil servant. Journal of Leadership in Organizations, 2(2). https:/ / doi.org/10.22146/jlo.55371

Trinkner, R., Jackson, J., \& Tyler, T. R. (2018). Bounded authority: Expanding appropriate police behavior beyond procedural justice. Law and Human Behavior, 42(3), 280-293. https: / / doi . org $/ 10.1037 / \mathrm{lhb} 0000285$

Tyler, T., Degoey, P., \& Smith, H. (1996). Understanding why the justice of group procedures matters: A test of the psychological dynamics of the group-value model. Journal of Personality and Social Psychology, 70(5), 913-930. https://doi.org/10.1037/0022-3514.70.5.913 


\section{Larasati et al || Literature Review of Social Identity}

Tyler, T. R. (1989). The psychology of procedural justice: A test of the group-value model. Journal of Personality and Social Psychology, 57(5), 830-838. https://doi.org/10.1037/0022-3514.57.5.830

Tyler, T. R. (2001). Public trust and confidence in legal authorities: What do majority and minority group members want from the law and legal institutions? Behavioral Sciences $\mathcal{E}$ the Law, 19(2), 215-235. https://doi.org/10.1002/bsl.438

Tyler, T. R. (2009). Procedural justice, identity and deference to the law: What shapes rule-following in a period of transition? Australian Journal of Psychology, 61(1), 32-39. https:/ / doi.org/10.1080/ 00049530802607639

Tyler, T. R., \& Blader, S. L. (2000). Cooperation in groups: Procedural justice, social identity, and behavioral engagement. Philadelphia, Psychology Press. https://psycnet.apa.org/record/2000-16593-000

Tyler, T. R., \& Blader, S. L. (2003). The group engagement model: Procedural justice, social identity, and cooperative behavior. Personality and Social Psychology Review, 7(4), 349-361. https: / / doi.org/ 10.1207/s15327957pspr0704_07

Tyler, T. R., \& Huo, Y. J. (2002). Trust in the law: Encouraging public cooperation with the police and courts. Russell Sage Foundation.

Tyler, T. R., \& Lind, E. A. (1992). A relational model of authority in groups. In Advances in experimental social psychology (pp. 115-191). Elsevier. https://doi.org/10.1016/s0065-2601(08)60283-x

Urbanska, K., \& Guimond, S. (2018). Swaying to the extrme: Group relative deprivation predicts voting for an extreme right party in the french presidential election. International Review of Social Psychology, 31(1). https://doi.org/10.5334/irsp.201

Urbanska, K., Pehrson, S., Platow, M. J., \& Turner, R. (2019). Authority fairness as contingent on intergroup attitudes: Review and expansion of relational models of procedural justice. Center for Open Science. https://doi.org/10.31234/osf.io/j9ndy

Wenzel, M. (2002). The impact of outcome orientation and justice concerns on tax compliance: The role of taxpayers' identity. The Journal of Applied Psychology, 87(4), 629-645. https: / / doi.org / 10. 1037/0021-9010.87.4.629

Yildiz, A. A., \& Verkuyten, M. (2012). We are not terrorists: Turkish muslim organizations and the construction of a moral identity. Ethnicities, 13(3), 359-381. https: / / doi . org / 10.1177 / 1468796812451219

Yulianti, P. (2016). Procedural justice, organizational trust, organizational identification dan pengaruhnya pada employee engagement. Journal of Theory and Applied Management, 9(3). https://doi.org/10.20473/jmtt.v9i3.3076

Zelmiyanti, R. (2016). Keadilan prosedur dan kepercayaan wp terhadap otoritas pajak: Analisis mediasi kepatuhan pajak [procedural justice and taxpayer trust towards the tax authorities: Mediation analysis of tax compliance]. Jurnal Riset Akuntansi \& Keuangan, 4(3), 1-11. https: //ejournal.upi.edu/index.php/JRAK/article/view/4662 